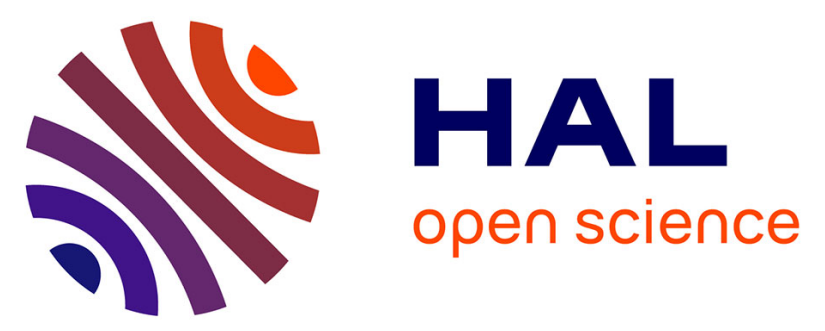

\title{
Numerical modelling of vertical suspended solids concentrations and irradiance in a turbid shallow system (Vaccares, Se France)
}

Bertrand Millet, Christian Robert, Patrick Grillas, Clare Coughlan, Damien Banas

\section{To cite this version:}

Bertrand Millet, Christian Robert, Patrick Grillas, Clare Coughlan, Damien Banas. Numerical modelling of vertical suspended solids concentrations and irradiance in a turbid shallow system (Vaccares, Se France). Hydrobiologia, 2010, 638 (1), pp.161-179. 10.1007/s10750-009-0038-9 . hal-00839350

\section{HAL Id: hal-00839350 https://hal.science/hal-00839350}

Submitted on 27 Jun 2013

HAL is a multi-disciplinary open access archive for the deposit and dissemination of scientific research documents, whether they are published or not. The documents may come from teaching and research institutions in France or abroad, or from public or private research centers.
L'archive ouverte pluridisciplinaire HAL, est destinée au dépôt et à la diffusion de documents scientifiques de niveau recherche, publiés ou non, émanant des établissements d'enseignement et de recherche français ou étrangers, des laboratoires publics ou privés. 


\title{
Numerical modelling of vertical suspended solids concentrations and irradiance in a turbid shallow system (Vaccares, Se France)
}

\author{
Bertrand Millet • Christian Robert • \\ Patrick Grillas · Clare Coughlan • \\ Damien Banas
}

Received: 3 September 2009/Revised: 23 November 2009/Accepted: 28 November 2009/Published online: 18 December 2009 (C) Springer Science+Business Media B.V. 2009

\begin{abstract}
In shallow ecosystems, the short temporal variability of available underwater irradiance is considered a major process controlling submerged macrophytes development. Mechanistic models that estimate photosynthetically available radiation (PAR) in shallow ecosystems at very short time scales are needed for use in predicting submerged macrophyte growth and persistence. We coupled a 2D horizontal circulation model with, first, a 1D vertical numerical model of suspended solid (SS) re-suspension, diffusion and settling, and next, with a model of vertical
\end{abstract}

Handling editor: Luigi Naselli-Flores

B. Millet $(\bowtie)$

Centre d'Océanologie de Marseille, UMR 6535,

Aix-Marseille Universités, Luminy Case 901,

13288 Marseille Cedex 9, France

e-mail: bertrand.millet@univmed.fr

C. Robert

CEREGE, Aix-Marseille Universités, BP 80,

13545 Aix-en-Provence Cedex 4, France

P. Grillas

Tour du Valat, Le Sambuc, 13200 Arles, France

C. Coughlan

Centre for Environment, Fisheries and Aquaculture

Sciences, Pakefield Road, Lowestoft NR33 OHT, UK

D. Banas

Univ. Nancy, UR-AFPA, INRA, 2 Av. Forêt Haye,

54505 Vandœuvre-lès-Nancy, France extinction of irradiance, previously validated at the same site. The study site was the Vaccarès lagoon (France) where a large data set of high frequency bottom irradiance and SS concentration were available. SS and irradiance measurements were conducted at a vertical study station, monitored over a 6 month period (from December 1995 to May 1996) characterized by wide-ranging wind velocities $\left(1.5-18 \mathrm{~ms}^{-1}\right)$. In addition, grain-size analyses conducted over the whole lagoon, allowed adaptation of the 1D numerical model to the silt-sized $(7 \mu \mathrm{m})$ and clay-sized $(0.3 \mu \mathrm{m})$ fractions that prevail in the local sediment. First, model results showed that about $60 \%$ of the variance in bottom irradiance time series can be explained by our deterministic formulations, thus representing the same level of efficiency than those already obtained by a stochastic model previously developed with the same data set. Second, model results showed that the fit of the model to the field data (SS concentrations and bottom irradiance) depended mainly on storm occurrence and season (winter or spring). Finally, model results suggested that the underwater irradiance regime was controlled by seasonal succession of the horizontal circulation of turbid water in the lagoon, with increased solids concentrations in winter, followed by submerged canopy development and decreased solids concentrations in spring.

Keywords Sediment resuspension .

Sediment settling - Vertical light extinction . 
Bottom irradiance - Submerged macrophytes . Numerical modelling

\section{Introduction}

Seagrass beds serve many important functions in shallow water bodies, primarily for their high primary and secondary production (e.g. Penhale, 1977, Zieman \& Wetzel, 1980; Edgar, 1999a, b; Pihl et al., 2006), but also as valuable feeding habitats for fish, decapods and cephalopods due to their high invertebrate biomasses (Edgar, 1999b, Kouchi et al., 2006). In addition, seagrasses play an important functional role in reducing the current velocity. Seagrasses development prevents re-suspension of suspended solids (SS) and promotes settling, thus accumulating fine particle sediment (Heiss et al., 2000). The importance of the seagrass beds is particularly highlighted when they disappear (Bernard et al., 2007).

Light availability and salinity are the main factors that control the distribution and production of submersed vegetation in shallow systems (e.g. Duarte, 1991; Vermaat et al., 2000). Underwater irradiance in shallow ecosystems may vary significantly at different time scales as a result of wind and storm events (Kristensen et al., 1992; Preen et al., 1995; Madsen et al., 2001; Banas et al., 2005), but also during events of direct or indirect anthropogenic origin such as eutrophication (Christofor et al., 1994; Best et al., 2001), biotic disturbances (Blindow, 1992) or salinity fluctuations. In the Vaccarès lagoon (SE France), salinity could indirectly affect underwater irradiance through its impact on bottom vegetation and the density of SSs (Charpentier et al., 2005). However, salinity fluctuations driven by changes in the balance between saltwater and freshwater in turn resulting from inputs from the catchments, evaporation and exchanges with the sea are relatively low in the Vaccarès lagoon. Therefore, light availability, which declines with water depth, the density of SS in the water column (especially phytoplankton and terrigenous particles) and the concentration of dissolved substances (e.g. humic acids), is critical in determining submerged vegetative growth in the Vaccarès lagoon.

In wind-exposed shallow aquatic systems, the importance of short-term fluctuations in underwater irradiance on the abundance and depth distribution of submersed macrophytes has been recognized (Zimmerman et al., 1994; Dunton, 1994; Moore et al., 1997; Longstaff \& Dennison, 1999). The Vaccarès lagoon is characterized by strong wind forcings. Therefore, SS vertical resuspension and horizontal transport at short time scales are considered the major processes controlling the distribution of particles and adsorbed compounds. These in turn greatly affect the amount of light available in the shallow water column. The relatively small dimensions of this shallow turbulent lagoon $\left(60 \mathrm{~km}^{2}\right.$ with a maximum depth of $2 \mathrm{~m}$ ), combined with a local wind regime characterized by unsteady strong and short wind events all year round, suggest permanent sediment redistribution within the lagoon controlled by windinduced currents and waves without regions of particle accumulation. The Vaccarès lagoon is appropriately characterized as a lagoon in which random redistribution of sediments predominates (Hilton, 1985).

Numerical models are generally considered as major research tools for highlighting biotic and physical processes interactions in complex ecosystems. Sophisticated coupled models based on complex biogeochemical algorithms have been recently developed to take into account both nutrient cycling and underwater irradiance impacts on phytoplankton or macrophyte dynamics in coastal lagoons (Plus et al., 2003; Byun et al., 2007; Aveytua-Alcazar et al., 2008; Sheng \& Kim, 2008). Nevertheless, in very turbid shallow systems under strong wind conditions, very short-term sediment re-suspension remains insufficiently documented in these sophisticated ecological models, which generally do not consider forcing related to short wind events (at hourly scale) and heterogeneous sediment grain-size. In the shallow Vaccarès lagoon, Banas et al. (2005) developed a stochastic model of irradiance vertical extinction that confirmed the significant correlation between short time scale wind velocities and the amount of underwater irradiance available at the bottom. This previous study showed a very short period of time $(1.5 \mathrm{~h})$ between increased wind velocity and increasing sediment resuspension. However, the closest relationship between irradiance and wind speed was observed by using the average wind speed observed during the previous $15 \mathrm{~h}$, probably because the particles can remain suspended in the water column for several hours (Banas et al., 2005). 
Our objectives were to develop a deterministic approach to describe and predict short-term fluctuations in underwater irradiance. First, we adapted a 2D horizontal circulation model (Millet \& Guelorget, 1994) to compute the wind-induced water circulation throughout the lagoon and to quantify the specific current velocities at our study station, according to the direction of the prevailing wind. Second, a 1D vertical model of the sediment re-suspension, diffusion and settling was adapted to our study station to compute the wind-induced vertical profile of SS concentrations. Finally, the underwater irradiance availability at our study station was deduced from these SS computations by using the algorithm of vertical extinction of irradiance previously validated at the same site by Banas et al. (2005).

\section{Methods}

Study site

The Vaccarès lagoon is a $66 \mathrm{~km}^{2}$ shallow and euryhaline water body (12 km long, $7 \mathrm{~km}$ wide, $1.4 \mathrm{~m}$ mean depth and $2 \mathrm{~m}$ maximum depth) that developed at the surface of the Rhône delta plain (SE France) during the late Holocene (Fig. 1). It overlies a substrate of cohesive, fine deposits of probable prodeltaic origin, which accumulated around 5,700 years before present and is bound to the South by sandy beach sediments (Mornès Beach Ridge) that accumulated around 4,000 years before present during an interval of relatively stable sea level (Vella et al., 2005). Seasonal water level fluctuations are usually limited to $\pm 0.3 \mathrm{~m}$ (Chauvelon, 1996). Freshwater supply from the catchment $\left(317 \mathrm{~km}^{2}\right)$ is essentially provided by four drainage canals connected to the Rhône River. The lagoon is indirectly connected to the sea through adjacent shallow lagoons and exchanges of water are controlled by sluices. Over the last 50 years, the Vaccarès has experienced large variations in salinity resulting from the complex interaction of rainfall, which is highly variable under Mediterranean climate, land use in the delta specifically the surface area of rice-fields that drain into the lagoon, and management of sluices between the sea and the lagoon. In addition, seasurges and floods from the Rhône River have occasionally had a significant impact on the lagoon. In this context, the extension and species composition of the submerged macrophyte communities have changed extensively. Potamogeton pectinatus, Ruppia cirrhosa and Myriophyllum spicatum dominated from the 1960s to the late 1970s and colonised to depths of 1.5 to $1.7 \mathrm{~m}$. These species were replaced in the 1980 s by Zostera noltii dominated
Fig. 1 General map of the Vaccarès lagoon (SE France), with the location of the study station and the pattern of local wind direction

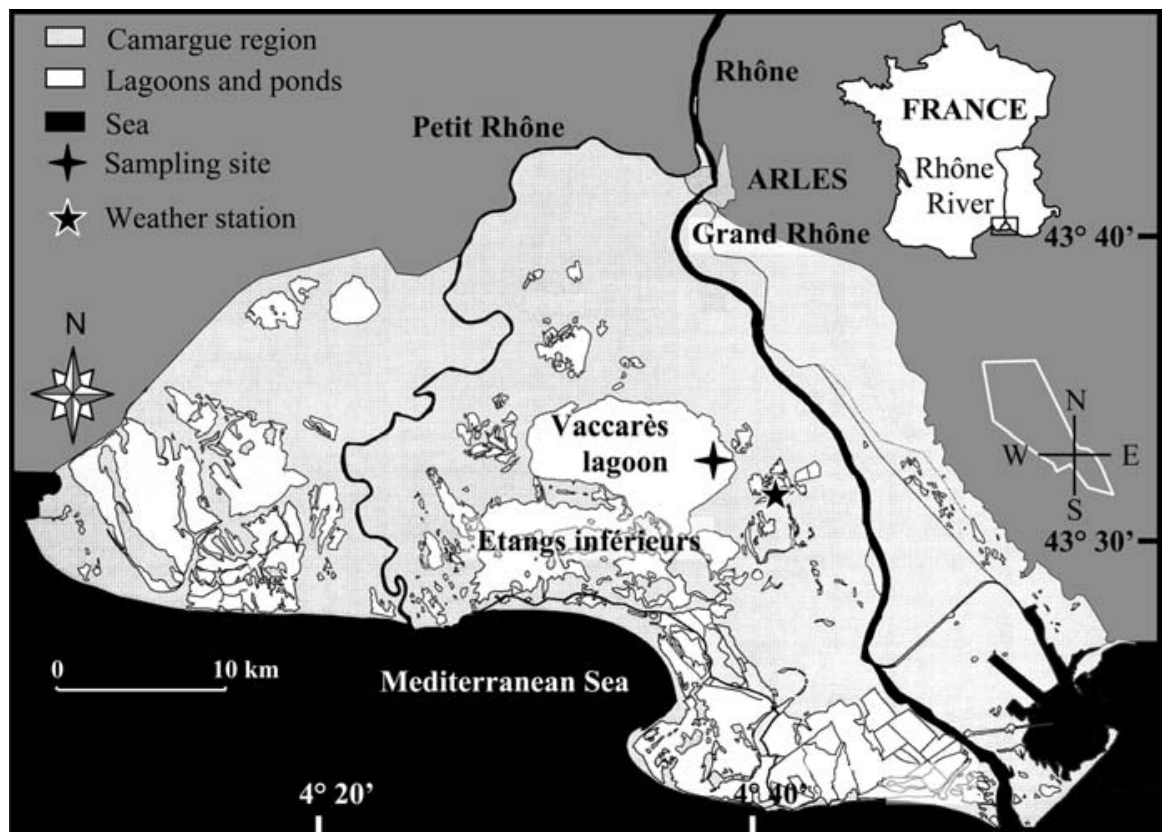


communities (with Lamprothamnium papulosum, $R$. cirrhosa, P. pectinatus), which reached maximum coverage in the early $1990 \mathrm{~s}$, extending to $1.8 \mathrm{~m}$ water depth with a total surface area of $45 \mathrm{~km}^{2}$. This seagrass bed experienced considerable inter-annual fluctuations (Charpentier et al., 2005), with an almost complete collapse in 1997 and a rapid recovery during the following years.

\section{Grain-size analyses}

The floor of the lagoon is capped by a thin layer of non-cohesive sediment. It is likely that flooding events of the Rhône River helped to maintain low salinities in the Vaccarès lagoon and also favoured the accumulation of terrigenous sediment particles. Particles of biological origin such as algae and shell fragments are rare in most surface sediments of the Vaccarès lagoon. Grain-size analyses have been conducted on 124 samples distributed over the whole Vaccarès lagoon, using a Malvern Mastersizer S laser sizer. Each sample was washed on a $500 \mu \mathrm{m}$ mesh sieve to remove the coarsest elements such as wood fragments. The sediment fraction less than $500 \mu \mathrm{m}$ was homogenized through centrifugation and stirring, then a quantity of sediment was dispersed into a sampler filled with 11 of water until an adequate concentration was reached (between 10 and $20 \%$ obscuration). Average values are used to compute grain-size parameters such as distribution curves and classes. For bulk and clay mineral investigations, 18 samples distributed along two transects across the lagoon $(\mathrm{N}-\mathrm{S}$ and $\mathrm{E}-\mathrm{W})$ have been selected and analyzed using a Philips PW 11850 diffractometer. Each sample was divided into two sub-samples. One sub-sample was crushed in a grinder and pressed into a holder for bulk mineral analyses. The other sub-sample was washed on a 63$\mu \mathrm{m}$ mesh sieve. The $<63 \mu \mathrm{m}$ fraction was decalcified using a solution of $10 \% \mathrm{HCl}$, rinsed with deionized water and deflocculated through repeated centrifugation. The clay fraction $(<2 \mu \mathrm{m})$ was separated by decantation and deposited onto a glass slide. X-ray diffraction analyses were conducted on natural clay slides after ethylene-glycol solvation and after heating at $490^{\circ} \mathrm{C}$ during $2 \mathrm{~h}$. Percentage evaluations were based on peak intensities (counts at maximum height). For clay quantification, the diagram obtained from the glycolated sample was used with weighting factors from Holtzapffel (1985).

\section{Monitoring}

Sediment re-suspension and transport in the Vaccarès lagoon are essentially controlled by hydrodynamic processes induced by strong winds. For this study, wind directions and velocities (10 m height) and the global incident irradiance were measured over $0.5 \mathrm{~h}$ intervals at the Meteo France weather station, located $6 \mathrm{~km}$ from the south-eastern shore of the Vaccarès lagoon. Wind velocities ranged from 1.5 and $18 \mathrm{~ms}^{-1}$ during the study period and the prevailing NW wind sector occurred $46 \%$ of the time (Fig. 1).

The study station for sampling SS concentrations and recording underwater irradiance was located $800 \mathrm{~m}$ from the East shore of the lagoon $\left(43^{\circ} 32^{\prime} 29.6^{\prime \prime} \mathrm{N}-4^{\circ} 38^{\prime} 04.1^{\prime \prime}\right.$ E, Fig. 1). Data loggers were installed on a $4 \mathrm{~m}^{2}$ platform. The amount of light made available to the submerged plants (i.e. PAR) was recorded continuously over 159 days using a spherical $(4 \pi)$ quantum sensor (LICOR Model 193 SA) from December 1995 to May 1996. The sensor was fitted at $0.36 \mathrm{~m}$ above the surface of the sediment (just above the top of $Z$. noltii bed) on a vertical rod set at $1 \mathrm{~m}$ off the south side of the platform. The sensor was covered with at least $1.0 \mathrm{~m}$ of water at all times and was cleaned semiweekly by scuba divers to prevent fouling. No measurable effect of fouling was detected when comparing the PAR values before and after cleaning. Underwater PAR was measured every $5 \mathrm{~s}$ and integrated over $0.5 \mathrm{~h}$.

Samples of water were collected at $1 \mathrm{~m}$ above the surface of the sediment using an automatic sampler (SIGMA 9000) located on the platform. These samples were collected at successive sampling periods in December 1995, February, April and May 1996. Duration of each sampling period varied from a minimum of $93 \mathrm{~h}$ to a maximum of $249 \mathrm{~h}$. Water samples $(1,000 \mathrm{ml})$ were composed of four sub-samples $(250 \mathrm{ml})$ collected every half hour and thus encompassed $2 \mathrm{~h}$ time intervals. A total of 386 samples were collected and SS were measured following the French standard methods for water analysis, with GFC filters dried at $105^{\circ} \mathrm{C}$ for $24 \mathrm{~h}$. The water level at the study station was 
interpolated half-hourly from data continuously recorded at a hydrology station located $1.5 \mathrm{~km}$ from the study site. The height of the water column at the study station as deduced from the water level records ranged from a minimum of $1.36 \mathrm{~m}$ to a maximum of $1.89 \mathrm{~m}$ in spring and winter, respectively.

\section{Modelling}

The numerical model used to compute wind-driven currents was a classical 2D horizontal model based on depth-integrated equations of the fluid dynamics. The model has been successfully used in different coastal areas (Millet, 1989; Millet \& Guelorget, 1994). The model computed depth-averaged current velocities at steady state for homogeneous water masses under a constant wind forcing. This system is solved by a classical semi-implicit ADI scheme (Alternating Direction Implicit) with a short time step of $1 \mathrm{~s}$. The model was adapted to the Vaccarès lagoon by using a $104 \times 74$ grid of regular $125-\mathrm{m}$ squared meshes, and bathymetries were considered from a 1/25,000 map available at the Tour du Valat (P. Grillas, unpublished). According to CERC (1975), the formulations considered to compute the height and the period of the wind-induced waves were as follows:

$$
\begin{aligned}
g \times H / W^{2}= & 0.283 \times \tan h\left[0.53 \times\left(g \times h / W^{2}\right)^{0.75}\right] \\
& \times \tan h\left[\left(0.0125 \times\left(g \times F / W^{2}\right)^{0.42}\right)\right. \\
& \left./\left(\tan h\left(0.53 \times\left(g \times h / W^{2}\right)^{0.75}\right)\right)\right](1)
\end{aligned}
$$

$$
\begin{aligned}
g \times & T /(2 \times \pi \times W) \\
= & 1.2 \times \tan h\left[0.833\left(g \times h / W^{2}\right)^{0.375}\right] \\
& \times\left[\tan h\left(0.077 \times\left(g \times F / W^{2}\right)^{0.25}\right)\right. \\
& \left./\left(\tan h\left(0.833 \times\left(\mathrm{g} \times \mathrm{h} / \mathrm{W}^{2}\right)^{0.375}\right)\right)\right]
\end{aligned}
$$

where $H$ is the wave height (m), $T$ is the wave period (s), $g$ is the gravity $\left(\mathrm{ms}^{-2}\right), h$ is the height of the water column (m), $F$ is the fetch $(\mathrm{m})$ and $W$ is the wind velocity $\left(\mathrm{ms}^{-1}\right)$.

The formulations to compute the bed shearstresses induced by the combined effect of currents and waves, and the rate of sediment resuspension $R$, were taken from the practical algorithms proposed by
Soulsby (1997). Bed shear-stress $\left(\tau_{\mathrm{C}}\right)$ induced by currents only was expressed as

$\tau_{\mathrm{C}}=\rho \times C_{\mathrm{d}} \times U^{2}$.

Time-averaged bed shear-stress $\left(\tau_{\mathrm{w}}\right)$ induced by waves only was expressed as

$\tau_{\mathrm{w}}=0.5 \times\left(\rho \times f_{\mathrm{w}} \times U_{\mathrm{w}}^{2}\right)$

where $C_{\mathrm{d}}=2.37 \times 10^{-3}$ is the drag coefficient computed from Soulsby (1997), $\rho=10^{3} \mathrm{~kg} \mathrm{~m}^{-3}$ is the water density; $U$ is the depth-averaged current velocity $\left(\mathrm{ms}^{-1}\right), f_{\mathrm{w}}$ is the wave friction factor, and $U_{\mathrm{w}}$ is the near-bed orbital velocity amplitude $\left(\mathrm{ms}^{-1}\right)$, which was expressed as

$\begin{aligned} U_{\mathrm{w}}= & (\pi \times H / T) \\ & \times\left(1 / \sin h\left[4 \times \pi^{2} \times H /\left(g \times T^{2}\right)\right]\right) .\end{aligned}$

The wave friction factor $\left(f_{\mathrm{w}}\right)$ adapted to rough turbulent flow was expressed as follows, still according to Soulsby (1997)

$f_{\mathrm{w}}=1.39 \times\left(A / z_{0}\right)^{-0.52}$

where $z_{0}=2 \times 10^{-4} \mathrm{~m}$ is the bed roughness length and $A$ is the near-bed orbital excursion (m), expressed as

$A=U_{\mathrm{w}} \times T /(2 \pi)$.

The resulting bed shear-stress $\left(\tau_{\mathrm{R}}\right.$ in $\left.\mathrm{Nm}^{-2}\right)$ due to the combined effects of both currents and waves was expressed as

$\tau_{\mathrm{R}}=\tau_{\mathrm{C}} \times\left(1+1.2 \times\left[\tau_{\mathrm{w}} /\left(\tau_{\mathrm{w}}+\tau_{\mathrm{C}}\right)\right]^{3.2}\right)$.

The threshold bed shear-stress $\left(\tau_{\mathrm{cr}}\right.$ in $\left.\mathrm{Nm}^{-2}\right)$ for re-suspension of each sediment fraction considered in this study (two fractions) was expressed as follows, according to Miller et al. (1977) and Peterson (1999)

$$
\begin{aligned}
\tau_{\mathrm{cr}}= & 118.03 \times 10^{-3} \times \rho \\
& \times\left[g \times\left(\rho_{\mathrm{s}}-\rho\right) / \rho\right]^{0.8} \times(d \times v)^{0.4}
\end{aligned}
$$

where $\rho_{\mathrm{s}}$ is the grain density $\left(\mathrm{kg} \mathrm{m}^{-3}\right), d$ is the grain diameter $(\mathrm{m})$ and $v$ is the kinematic viscosity of the water. We considered the kinematic viscosity of fresh water at temperature $20^{\circ} \mathrm{C}: v=10^{-6} \mathrm{~m}^{2} \mathrm{~s}^{-1}$. Finally, the rate of sediment re-suspension $\left(R\right.$ in $\left.\mathrm{kg} \mathrm{m}^{-2} \mathrm{~s}^{-1}\right)$ by surface units and for each sediment fraction considered under the combined effect of currents and waves was 
$R=C_{\mathrm{M}} \times\left[1-\left(\tau_{\mathrm{cr}} / \tau_{\mathrm{R}}\right)\right]$

where $C_{\mathrm{M}}$ is the maximal rate of re-suspension for each sediment fraction considered $\left(\mathrm{kg} \mathrm{m}^{-2} \mathrm{~s}^{-1}\right)$. This formulation for re-suspension rate was only valid for positive values $(R>0)$, while the resulting bed shear-stress $\left(\tau_{R}\right)$ dominated the threshold value $\left(\tau_{\mathrm{cr}}\right)$.

The formulations to compute the vertical settling velocities ( $w_{\mathrm{s}}$ in $\mathrm{ms}^{-1}$ ) of each sediment fraction considered were given by Soulsby (1997) as follows:

$w_{\mathrm{s}}=v / d \times\left\{\left[(10.36)^{2}+1.049 \times\left(\mathrm{D}^{*}\right)^{3}\right]^{0.5}-10.36\right\}$

with $\left(D^{*}\right)$, the dimensionless grain size given by

$D^{*}=d \times\left[g / v^{2} \times\left(\rho_{\mathrm{s}}-\rho\right) / \rho\right]^{1 / 3}$.

The resulting rate of SS settling ( $S$ in $\mathrm{kg} \mathrm{m}^{-2} \mathrm{~s}^{-1}$ ) for both fractions considered simultaneously was

$S=\Sigma i\left(w_{\mathrm{s}}(i) \times C(i)\right) \times\left[1-\tau_{\mathrm{R}} / \tau_{\mathrm{s}}\right]$

where $C(i)$ and $w_{\mathrm{s}}(i)$ is the concentration $\left(\mathrm{mg} \mathrm{l}^{-1}\right)$ and the settling velocity $\left(\mathrm{ms}^{-1}\right)$ of each sediment fraction (i) considered in this study and computed at the bottom layer of the water column, $\left(\tau_{\mathrm{s}}\right)$ the threshold bed shear-stress for sediment settling $\left(\mathrm{Nm}^{-2}\right)$ and $\left(\tau_{\mathrm{R}}\right)$ the resulting bottom stress due to the combined effects of both currents and waves $\left(\mathrm{Nm}^{-2}\right)$. In order to emphasize the settling processes of all the sediment fractions in the water column, we considered $\left(\tau_{\mathrm{s}}=10 \mathrm{Nm}^{-2}\right)$, a high and constant value published by Vlag (1992) for similar wind-exposed shallow systems. SS concentrations of both sediment fractions considered in our study were computed by the vertical diffusion-settling model proposed by Vlag (1992). This simple model solved the differential equation of the balance between upwards turbulent diffusion and downwards SS particles settling in the water column

$\delta C / \delta t+\delta\left(w_{\mathrm{s}} \times C\right) / \delta z=\delta / \delta z\left(E_{z} \times \delta C / \delta z\right)$

where $C$ is the SS concentration $\left(\mathrm{mg} \mathrm{l}^{-1}\right), w_{\mathrm{s}}$ is the settling velocity of $\mathrm{SS}\left(\mathrm{ms}^{-1}\right)$ and $E_{z}$ is the vertical eddy diffusion coefficient $\left(\mathrm{m}^{2} \mathrm{~s}^{-1}\right)$ depending on the depth $(z)$ and given by the classical equation of vertical parabolic distribution in the water column (Vlag, 1992; Soulsby, 1997)

$E_{z}=\kappa \times\left(U^{*}\right) \times z \times(1-z / h)$

where $\kappa=0.4$ is the Von Karman constant, $z$ is the depth considered in the water column summed from the water surface (m), $h$ is the maximum height of the water column (m) and $U^{*}$ is the bottom friction velocity $\left(\mathrm{ms}^{-1}\right)$ given by the equation proposed by Soulsby (1997)

$U^{*}=\left(C_{\mathrm{d}}\right)^{0.5} \times U$

where $C_{\mathrm{d}}$ the bottom drag coefficient as in Eq. 3 and $U$ the depth-averaged current velocity.

The vertical diffusion-settling model was successively solved for each sediment fraction considered in our study with an explicit resolution, three vertical layers and a time step of $10 \mathrm{~s}$. At each time step and at each vertical layer SS concentrations were computed by the diffusion-settling model with the sediment fractions. Then, resulting values of SS concentrations $\left(C_{\text {res }}\right.$ in $\left.\mathrm{mg} \mathrm{l}^{-1}\right)$ available at each vertical layer of the model were obtained by summing the computed concentrations of each fraction. Model computations were forced at each time step of $0.5 \mathrm{~h}$ by measurements recorded at the same frequency: the water level of the lagoon, the wind velocity $(W)$, the wind direction and the corresponding fetch $(F)$ at the study station. Wind velocities lower than $1.5 \mathrm{~ms}^{-1}$ were disregarded in the model as they are not considered to impact hydrodynamics in the lagoon. In order to find the best fit between model results and measurements, $W$ and $F$ forcing functions were considered to have a lag of $2 \mathrm{~h}$ before any given time step of computation, according to the previous study of Banas et al. (2005). Finally, underwater irradiance time series (I) were computed at the specific depth $\left(z_{i}\right)$ corresponding to the location of the irradiance measurements. This computation took into account the incident irradiance $\left(I_{0}\right)$ measured at the weather station and the SS concentrations $\left(C_{\text {res }}\right)$ previously computed by the vertical diffusion-settling model.

First, incident irradiances $I_{0}$ were converted in PAR $_{0}\left(\mu \mathrm{E} \mathrm{m}^{-2} \mathrm{~s}^{-1}\right)$ just beneath the water surface, according to the following equation proposed by Banas et al. (2005) 
$\mathrm{PAR}_{0}=I_{0} \cdot C_{\mathrm{sph}} \times m_{0} \times m_{1}$

where $C_{\mathrm{sph}}=1.27$ is the mean spherical correcting coefficient recommended by Stefan et al. (1983) and used by Banas et al. (2005); $m_{0}=0.45$ is the PAR coefficient corresponding to the photosynthetically active radiation and $m_{1}=0.94$ is the albedo coefficient. Second, PAR time series were computed at the sampling depth $\left(z_{i}\right)$, which was chosen to position the Licor sensor just above the seagrass canopy at $0.36 \mathrm{~m}$ above the bottom sediment layer. PAR time series were computed by the Lambert-Beer equation previously calibrated by Banas et al. (2005)

$\mathrm{PAR}=\mathrm{PAR}_{0} \times \exp \left(-\lambda \times z_{i}\right)$

where $\lambda$ is the vertical attenuation coefficient for PAR computed from the equation

$\lambda=K_{\mathrm{wc}} \times z_{i}+E_{\mathrm{SS}} \times C_{\mathrm{int}}$

where $K_{\mathrm{wc}}=0.683 \mathrm{~m}^{-1}$ is the attenuation coefficient due to water, coloured dissolved substances and chlorophyll pigments, $E_{\mathrm{SS}}=0.027 \mathrm{~m}^{2} \mathrm{~g}^{-1}$ is the attenuation coefficient due to SS in the water column and $C_{\text {int }}$ is the resultant SS $\left(\mathrm{g} \mathrm{m}^{-2}\right)$ computed from the concentration $\left(C_{\text {res }}\right)$ vertically integrated from the surface to the sampling depth $\left(z_{i}\right)$.

The model calibration consisted in computing the optimal values for the maximum rates of re-suspension $C_{\mathrm{M}}$ (clay) and $C_{\mathrm{M}}$ (silt) relating to both fractions considered in the model. A classical quadratic adjustment criterion was used to find the best fit between the computed and measured irradiance time series, as follows:

$\left\{1 / n \times \Sigma_{i, n}\left[\left(I-I_{\mathrm{obs}}\right) / I_{\mathrm{obs}}\right]^{2}\right\}^{0.5}$

where $n$ is the number available values, $I$ and $I_{\text {obs }}$ are the computed and measured irradiances, respectively.

\section{Results}

\section{Sediment}

Distribution maps (Fig. 2) show that silt-sized (63$4 \mu \mathrm{m})$ and clay-sized $(4-0.2 \mu \mathrm{m})$ particles largely dominated in most surface sediments of the Vaccarès lagoon, with fine and very fine sands $(250-63 \mu \mathrm{m})$ increasing in importance in the southern part of the lagoon where they prevailed in close proximity to a fossil sandy beach (Mornès Beach Ridge). Colloids $(<0.2 \mu \mathrm{m})$ were also present, in minor amounts $(<3 \%)$. Most grain-size frequencies were concentrated about a mode which varies between 5 and $10 \mu \mathrm{m}$ in the northern and central parts of the lagoon. Grain-size frequencies between 200 and $300 \mu \mathrm{m}$ were principally found in the southernmost part of the lagoon. Samples characterized by several frequency modes of similar amplitude, between 10 and $200 \mu \mathrm{m}$, were occasionally found. In addition, secondary frequency modes centered at $0.3 \mu \mathrm{m}$ occurred in most samples. In other parts of the lagoon, silt-sized particles largely dominate and may represent up to $80 \%$ of the sediment. In the northernmost part of the lagoon, samples characterized by several frequency modes ranging from 50 to $0.3 \mu \mathrm{m}$ are commonly found. In the central as well as in the eastern part of the Vaccarès lagoon near our study station, silt-sized particles (50-60\%) are associated with clay-sized. Figure $3 \mathrm{~A}$ and $\mathrm{B}$ presents representative grain-size distributions from the southern and northern parts of the lagoon, respectively. Figure $3 \mathrm{C}$ presents a distribution representative from the central and the eastern part of the lagoon (study station area), with patterns featured by a major and a minor peak in frequency, corresponding to very fine silt and fine clay/colloid fraction, respectively. We chose to adapt our vertical diffusion-settling model to the sediment fractions that dominated in the eastern part of the lagoon, i.e. a very fine silt (mode centered at $7 \mu \mathrm{m}$ ) and a fine clay fraction (mode centered at $0.3 \mu \mathrm{m}$ ). The respective densities corresponding to the two selected fractions were taken as $\rho_{\mathrm{s}}=2,720 \mathrm{~kg} \mathrm{~m}^{-3}$ for the fine clay and $\rho_{\mathrm{s}}=2,650 \mathrm{~kg} \mathrm{~m}^{-3}$ for the very fine silt (Deer et al., 1992).

\section{Modelling}

Wind-induced vertical averaged currents (Fig. 4a) and resulting bed shear-stresses $\left(\tau_{\mathrm{R}}\right.$ in $\left.\mathrm{Nm}^{-2}\right)$ due to the combined effects of both currents and waves (Fig. $4 \mathrm{~b}$ ) were computed by the 2D circulation model under the prevailing wind condition: NW $315^{\circ}$, $8 \mathrm{~ms}^{-1}$ (Fig. 1). Results confirmed the high energy level of the wind-induced hydrodynamics in the lagoon, with a mean current velocity of $8 \mathrm{~cm}^{-1}$ computed over the whole lagoon and a maximum current velocity of $26 \mathrm{~cm}^{-1}$ along the southern shore 
Fig. 2 Spatial repartition of the granulometry of the surface sediment in the Vaccarès lagoon
Fig. 3 Grain-size

distribution in the Vaccarès lagoon. A The fine silt and fine clay fractions are diluted within dominant sand-sized quartz in the southernmost part of the lagoon, near the Mornès Beach Ridge. B The dominant fine silt fraction shows an asymetrical distribution and is associated to variable quantities of clay and fine clay in the northernmost part of the lagoon. $\mathbf{C}$ The dominant fine silt and fine clay fractions show distinct frequency modes centered around 7 and $0.3 \mu \mathrm{m}$, respectively, in the central and eastern parts of the lagoon, including the study area
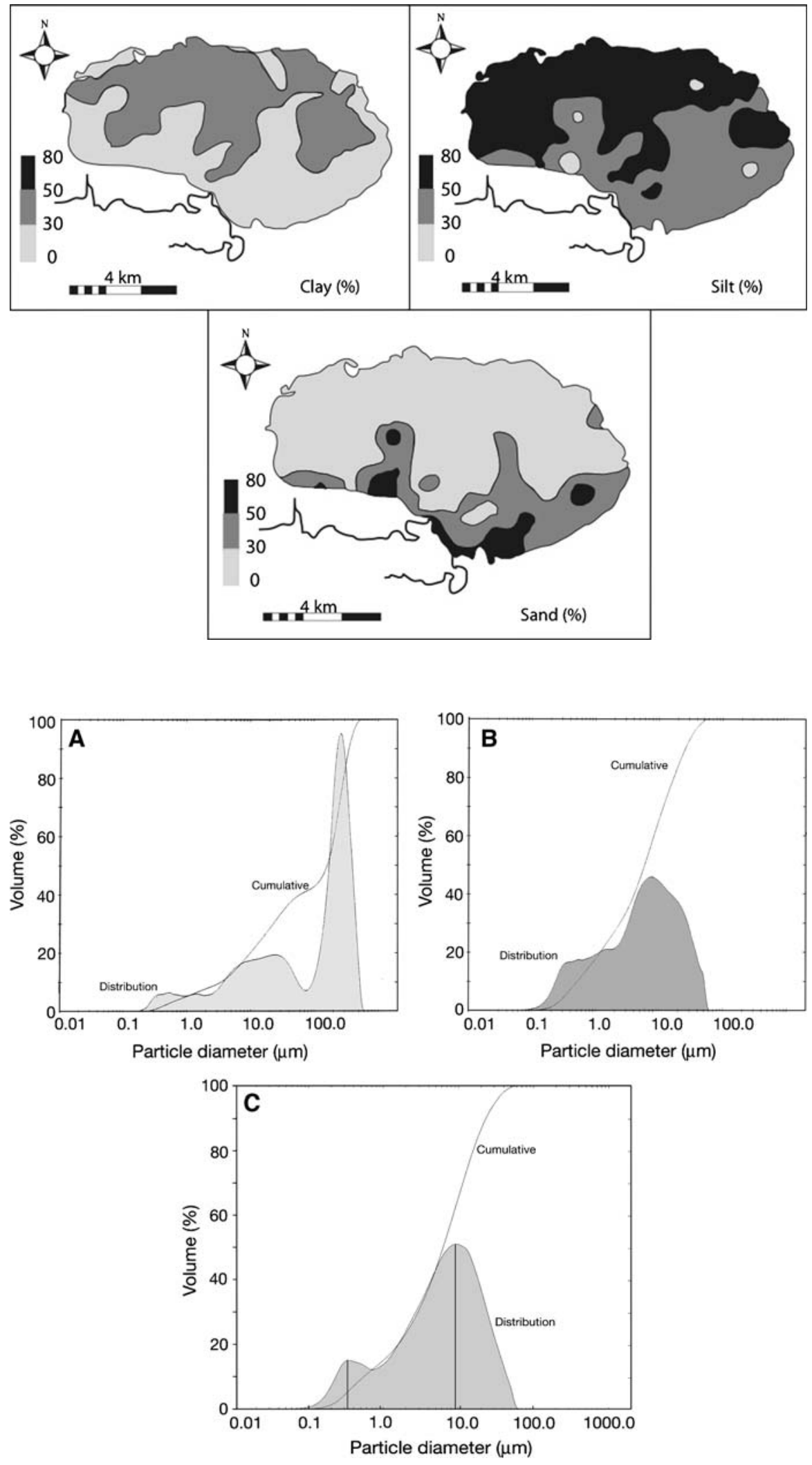
Fig. 4 Results of the 2D hydrodynamic model under the prevailing $\mathrm{NW} 315^{\circ}$, $8 \mathrm{~ms}^{-1}$ wind forcing, with study station location (asterisk): a wind-induced current velocity field superposed on bathymetry (mean and maximum velocity $=8$ and $26 \mathrm{~cm}^{-1}$ ); b resulting bottom shear stress field induced by the combined effect of currents and waves (expressed in $10^{-2} \mathrm{Nm}^{-2}$ )

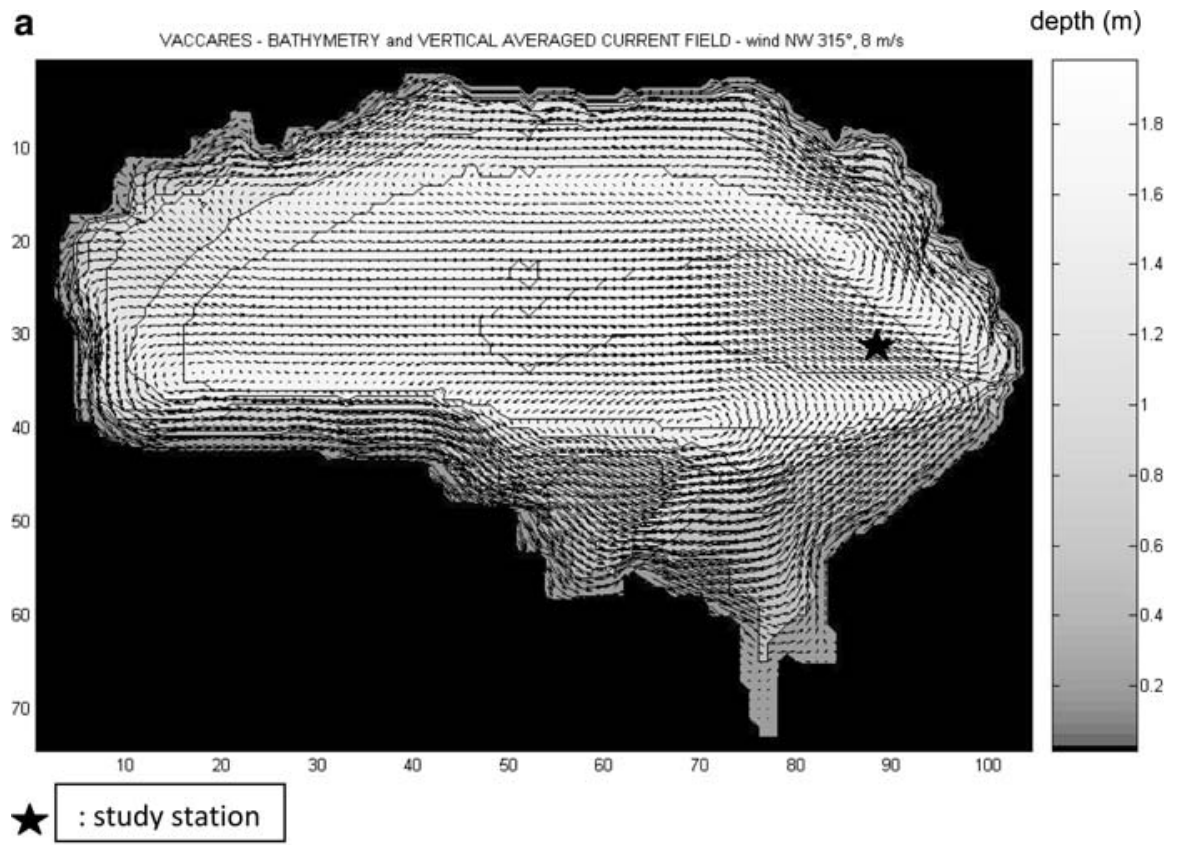

b

bottom stress

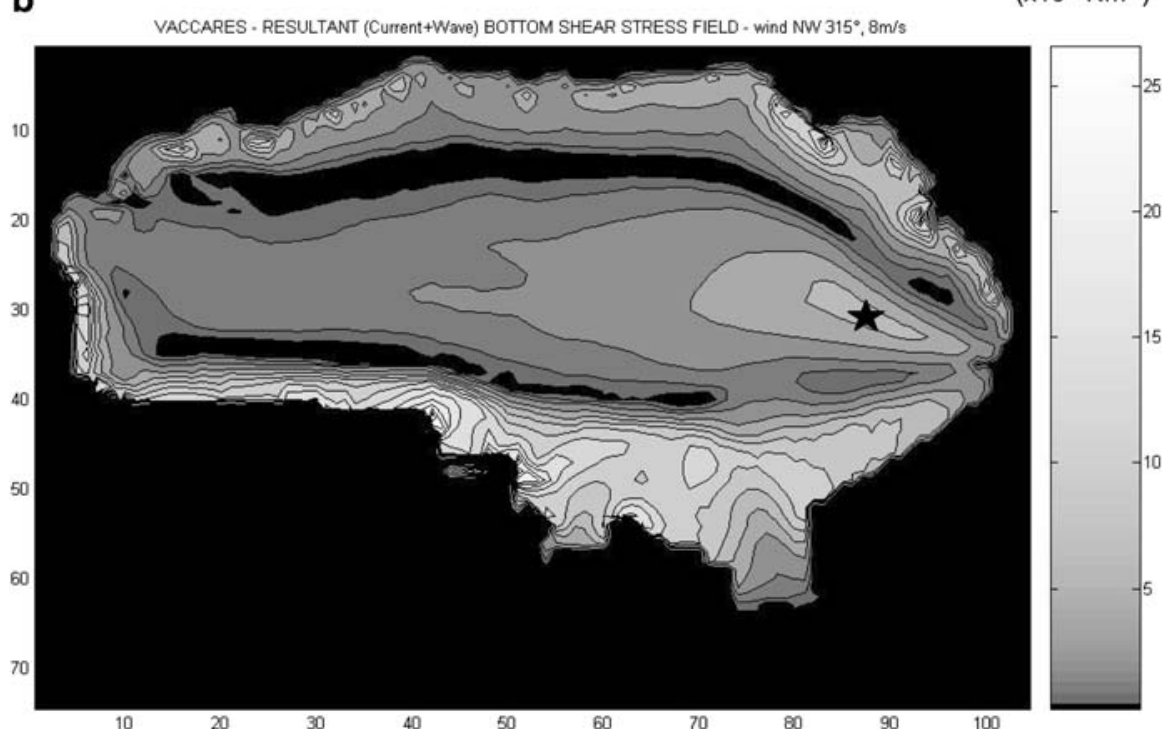

(Fig. 4a). Moreover, results showed that the highest values of bed shear stress induced by both currents and waves, ranging from 0.1 to $0.23 \mathrm{Nm}^{-2}$, occurred along the southern shore, which was characterized by a strong influence of NW winds with maximum fetch value reaching 9,275 m (Fig. 4b).

Prevailing wind-induced surface elevations reached maximum values of $11 \mathrm{~cm}$ along the northern (negative) and southern (positive) coastlines, and moderate values of $4 \mathrm{~cm}$ at our study station. This representative and prevailing value of surface elevation was considered too small in comparison with the height of the water column to significantly impact the vertical extinction of irradiance, and we did not take into account wind-induced surface elevations in our study. Fetch at the study station ranged from a minimum of $1,250 \mathrm{~m}$ to a maximum of $11,375 \mathrm{~m}$, according to E-SE $120^{\circ}$ and $\mathrm{W} 270^{\circ}$ wind sectors, 
respectively. The fetch corresponding to the prevailing NW $315^{\circ}$ wind sector was $F=3,350 \mathrm{~m}$.

In addition, similar current fields in the lagoon were successively computed by the $2 \mathrm{D}$ model for each wind sector and all intensities occurring over a year in the Vaccarès area (not shown). These computations led to an exhaustive and representative set of computed current velocities available at each mesh of the model. We generalized all these deterministic data available at the mesh corresponding to our study station, through a regression that linked the depth-averaged current velocities $\left(U\right.$ in $\left.\mathrm{ms}^{-1}\right)$ locally computed by the 2D model, to the corresponding wind velocities $\left(W\right.$ in $\mathrm{ms}^{-1}$ ) for each wind direction considered

$$
\begin{aligned}
& U=\left(11.1011 \times 10^{-3} \times \mathrm{W}-14.2234 \times 10^{-3}\right) \\
& \quad(n=36, R=0.857)
\end{aligned}
$$

This formulation was used to compute the depthaveraged current velocities $(U)$ in the $1 \mathrm{D}$ vertical model of SS re-suspension (cf. Eq. 3 and 16), according to only the observed wind velocities $(W)$ occurring during the 6-month period of our study, irrespective of direction.

Having identified the two fractions of sediment to be considered in our study as a fine clay $(d=0.3 \mu \mathrm{m})$ and a very fine silt $(d=7 \mu \mathrm{m})$ with their respective densities, some additional parameters of the 1D vertical model of the sediment diffusion and settling were computed. The threshold bed shear-stresses $\left(\tau_{\mathrm{cr}}\right)$ and the settling velocities $\left(w_{\mathrm{s}}\right)$ corresponding to each fraction were computed from Eqs. 9 and 11, respectively: $\tau_{\mathrm{cr}}=1.11 \times 10^{-2} \mathrm{Nm}^{-2}$ and $w_{\mathrm{s}}=2 \times 10^{-6} \mathrm{~ms}^{-1}$ for the fine clay; $\tau_{\mathrm{cr}}=3.78 \times 10^{-2} \mathrm{Nm}^{-2}$ and $w_{\mathrm{s}}=$ $4 \times 10^{-5} \mathrm{~ms}^{-1}$ for the very fine silt. This settling velocity was within the range of values from Lake Marken $\left(2 \times 10^{-5}<w_{\mathrm{s}}<9 \times 10^{-5} \mathrm{~ms}^{-1}\right.$ for siltsized sediment; Vlag, 1992). Initial conditions $\left(C_{0}\right.$ (clay) $)$ and $\left(C_{0}\right.$ (silt)) for SS concentrations of each fraction were quantified by considering the basic SS concentration $C=25 \mathrm{mg} \mathrm{l}^{-1}$ observed in absence of wind during the full sampling period, and the measured relative proportions of clay (20\%) and silt (80\%): $C_{0}$ (clay) $=5 \mathrm{mg} \mathrm{l}^{-1}$ and $C_{0}$ (silt) $=20 \mathrm{mg} \mathrm{l}^{-1}$.

First, the 1D vertical diffusion-settling model was calibrated against the time series of SS and irradiance measured in February 1996 ( $n=1,344$ steps of 0.5 h). February 1996 was chosen for model calibration as measurements then are representative of the site variability, with a wide range of values during a contrasted succession of weak and strong wind events. Figure $5 \mathrm{a}$ and $\mathrm{b}$ presents the results of the calibrated model with a comparison of the computed and measured time series of SS and irradiance, respectively, in February 1996. The coefficient of determination applied to irradiance time series was $r^{2}=0.45(P<0.001, n=1,344)$. Computed and measured time series showed an optimal fit, according to our adjustment criterion, when the following values were chosen for the re-suspension rates of both fractions: $C_{\mathrm{M}}$ (clay) $=1.2 \times 10^{-5} \mathrm{~kg} \mathrm{~m}^{-2} \mathrm{~s}^{-1}$ and $C_{\mathrm{M}}$ (silt) $=8 \times 10^{-5} \mathrm{~kg} \mathrm{~m}^{-2} \mathrm{~s}^{-1}$. These values of re-suspension rates were in agreement with the empirical values published by Winterwerp (1989; in Vlag, 1992), which range from $10^{-5}$ to $40 \times 10^{-5} \mathrm{~kg}$ $\mathrm{m}^{-2} \mathrm{~s}^{-1}$. The computed time-series of SS in February 1996 (Fig. 5a) had peaks of similar amplitude to the measurements, especially for medium concentrations that ranged from 50 to $600 \mathrm{mg}^{-1}$. Maximum computed concentrations reaching as much as $1,400 \mathrm{mg} \mathrm{l}^{-1}$ did not correlate with any available observations. The computed time-series of irradiance for February 1996 (Fig. 5b) showed a similar variability to measurements within the first half of the month corresponding to a moderate wind forcing, whereas they were over-estimated at the end of the month after bottom irradiance strongly decreased (beyond 1,100 time steps of computation). Computed irradiances even disappeared during a strong wind event between 600 and 1,100 time steps of computation.

Second, the calibrated 1D vertical diffusion-settling model was run for validation to compute the 5 monthly time series of SS and irradiance in December 1995, January, March, April and May 1996. Figure 6a-e shows a comparison of the computed monthly SS time series with measured SS concentrations. Figure $7 \mathrm{a}$ to e shows a comparison between the computed and measured monthly irradiance time series. For additional information, Fig. 8a-f shows the diagrams of regression between computed versus measured underwater irradiances over the whole period, including February 1996. All the SS time series computed in the validation period presented similar amplitudes to measurements for medium concentrations ranging from 30 to 600 $\mathrm{mg}^{-1}$. The maximum computed SS concentration was about 2,000 $\mathrm{mg}^{-1}$ in March 1996 (Fig. 6). The computed monthly irradiance time series (Fig. 7) 
Fig. 5 Model calibration: time series of computed results in February 1996 compared with observations: a suspended solid concentrations; b irradiances $\left(r^{2}=0.45\right)$, at the study station and at the sampling depth, $0.36 \mathrm{~m}$ above the seagrass canopy
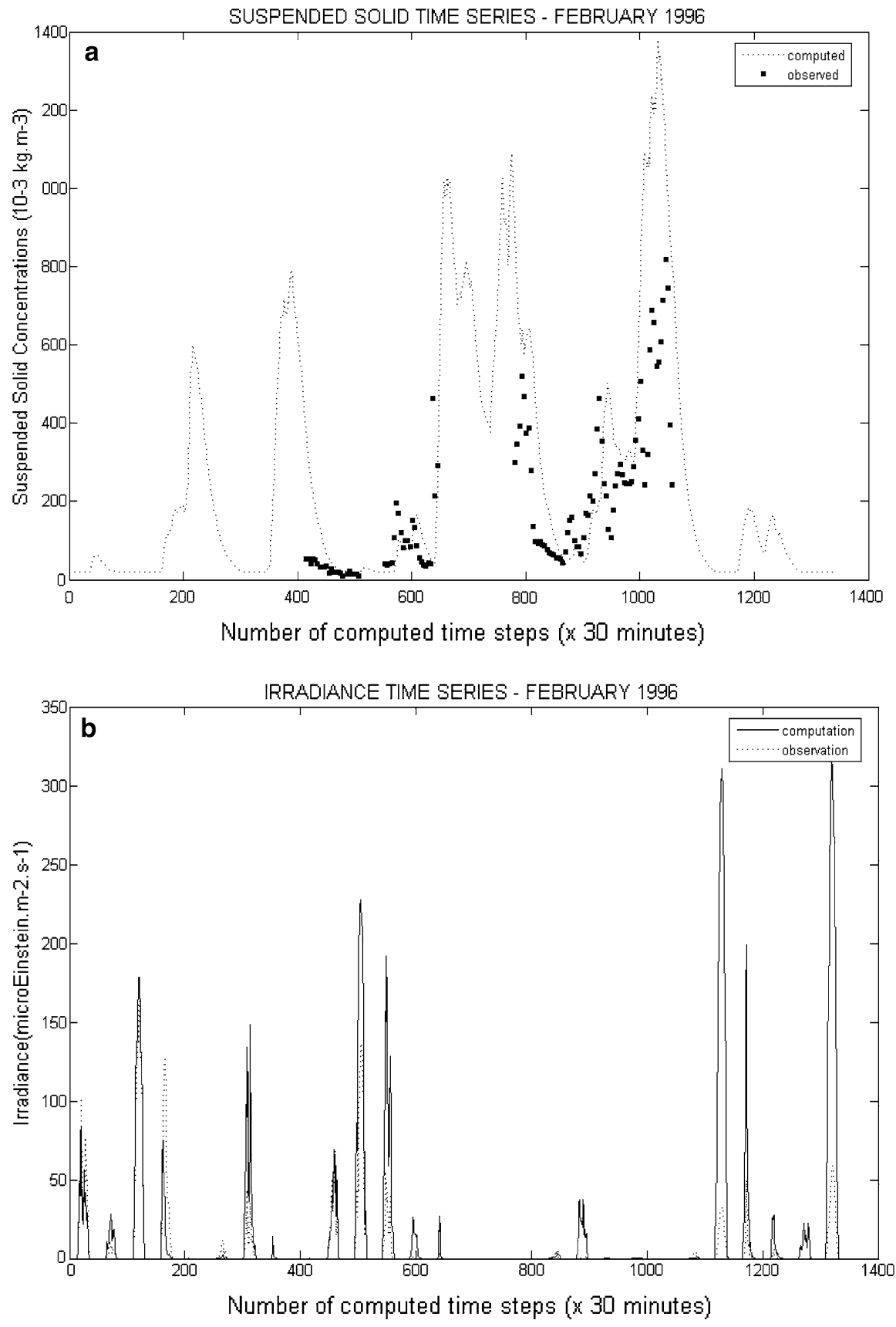

mainly varied with storm occurrence and seasonality. Actually, computed and measured irradiances showed different levels of correlation, depending on the period of investigation: December $1995\left(r^{2}=0.65\right.$, $P<0.001, n=768)$; January $1996 \quad\left(r^{2}=0.78\right.$, $P<0.001, n=1,488)$; March $1996\left(r^{2}=0.69, P<\right.$ $0.001, n=1,488)$; April $1996\left(r^{2}=0.64, P<0.001\right.$, $n=1,440)$ and May $1996\left(r^{2}=0.58, P<0.001\right.$, $n=1,055)$. The analysis of the adequation between predicted and measured time series of irradiance, in terms of $r^{2}$ and RMSE both computed from the stochastic (Banas et al., 2005) and the determinist 1D vertical model, are comparatively presented in Table 1.

Results of the 1D vertical model are synthetically presented in Table 2. This allowed a comparison of 

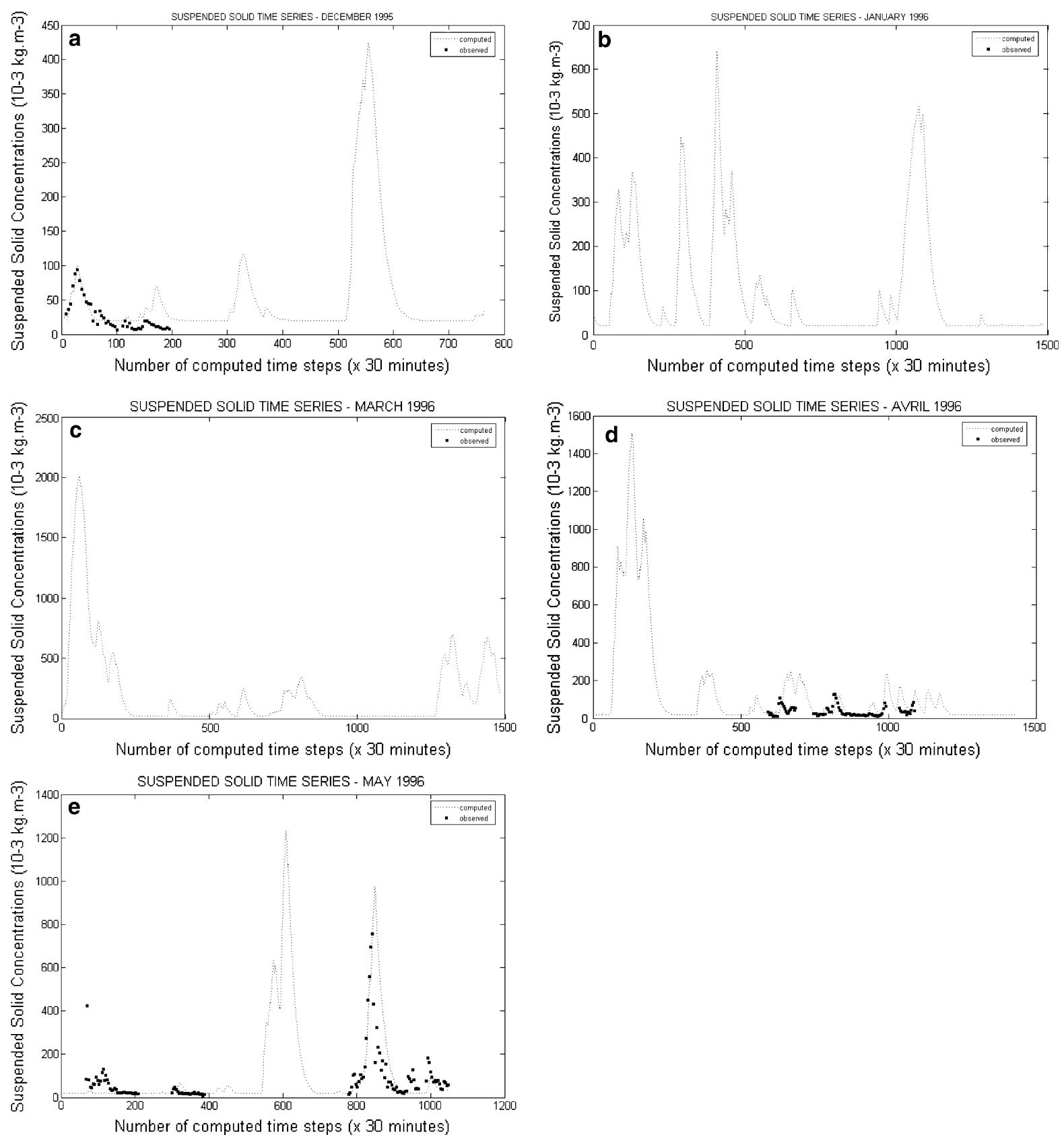

Fig. 6 Model validation results: times series of computed and observed suspended solid concentrations at the study station and at the sampling depth $0.36 \mathrm{~m}$ above the seagrass canopy,

from a December 1995; b January 1996; c March 1996; d April 1996 and e May 1996. Beware of different scales on y-axis

the monthly variations of wind-induced bottom stress and the corresponding frequencies (\% of time) of occurrence for both SS fractions resuspension and three progressive levels of bottom irradiance, successively ranged between 0 and 1\%; 1 and 10\%:10 and $50 \%$ of the surface irradiance. Results showed that

periods of active SS resuspension were mainly controlled by the intensity of the wind-induced bottom stress, with minimum and maximum resuspension reaching 20.3 and $41.5 \%$ of the time in January and February, respectively. Highest values of bottom irradiance less than $50 \%$ of surface irradiance 

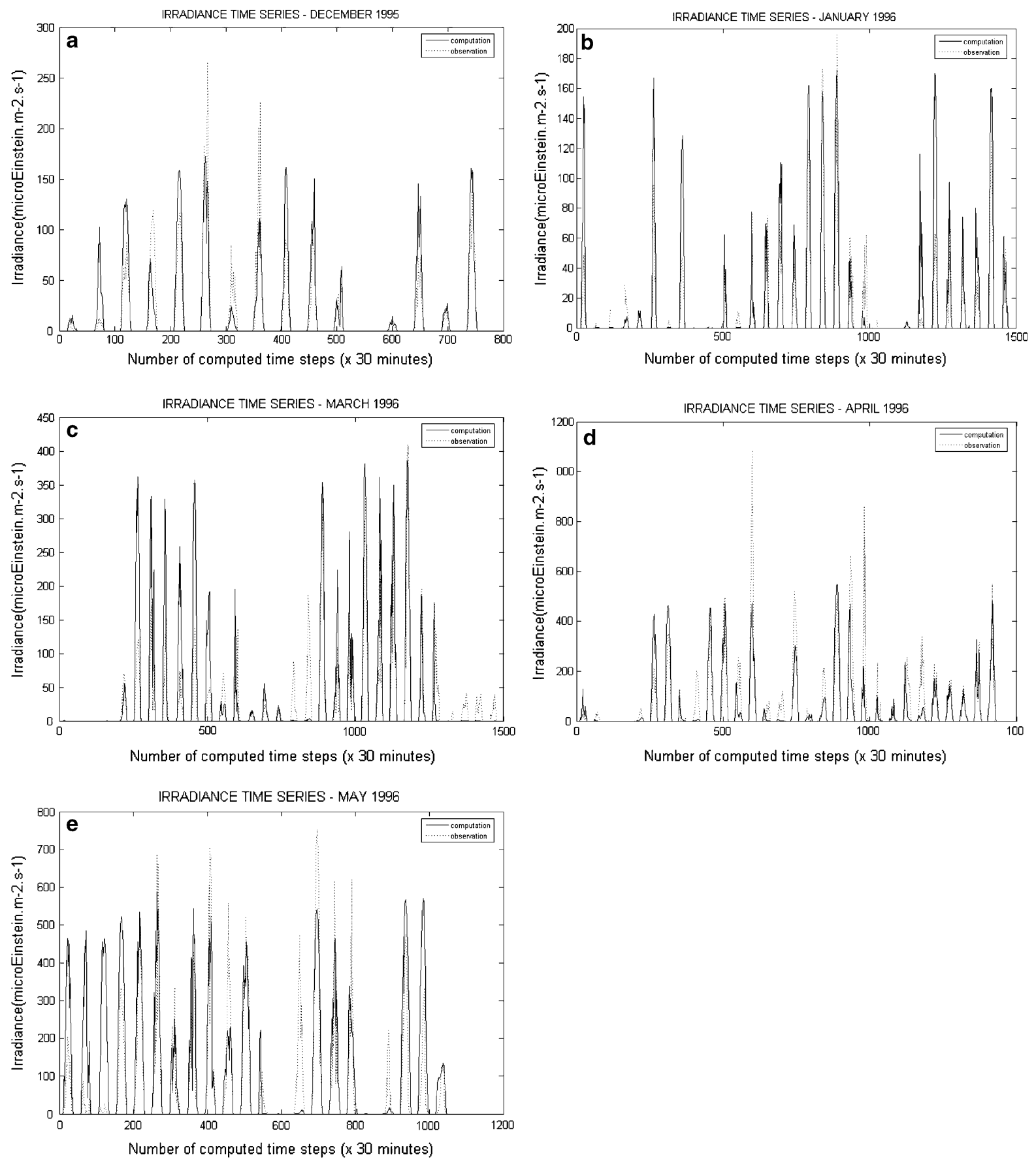

Fig. 7 Model validation results: times series of computed and observed irradiance at the study station and at the sampling depth $0.36 \mathrm{~m}$ above the seagrass canopy, from a December

occurred more than half of each monthly time, except in February where high irradiance occurred only $32 \%$ of the time. Inversely, lowest values of bottom

1995, $r^{2}=0.65$; b January 1996, $r^{2}=0.78$; c March 1996, $r^{2}=0.69 ; \mathbf{d}$ April 1996, $r^{2}=0.64$ and e May 1996, $r^{2}=0.58$. Beware of different scales on $y$-axis

irradiance less than $1 \%$ of surface irradiance occurred $52 \%$ of the time in February and ranged between 10 and $32 \%$ of the time in other periods. 
Fig. 8 Diagrams of one-toone regression between computed versus observed irradiance at the study station and at the sampling depth $0.36 \mathrm{~m}$ above the seagrass canopy, from a December 1995; b January 1996; c February 1996; d March 1996; e April 1996 and f May 1996 a irradiance - December 1995

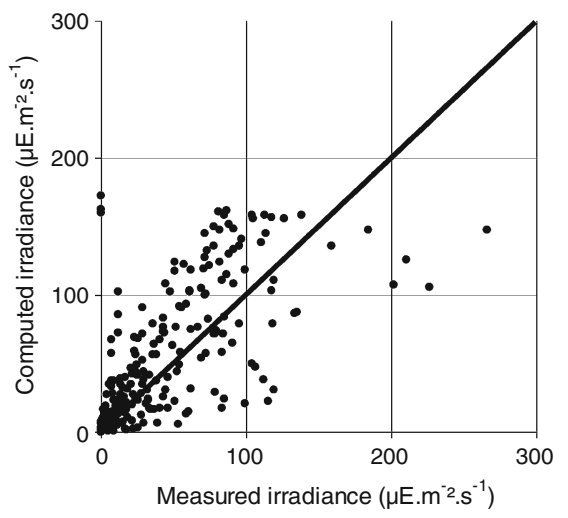

C irradiance - February 1996

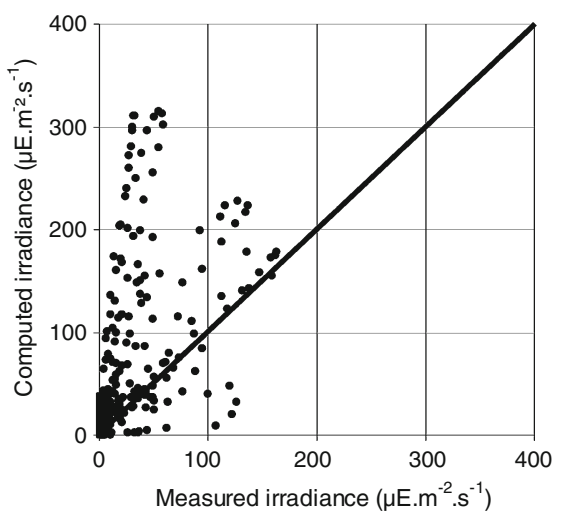

e irradiance - April 1996

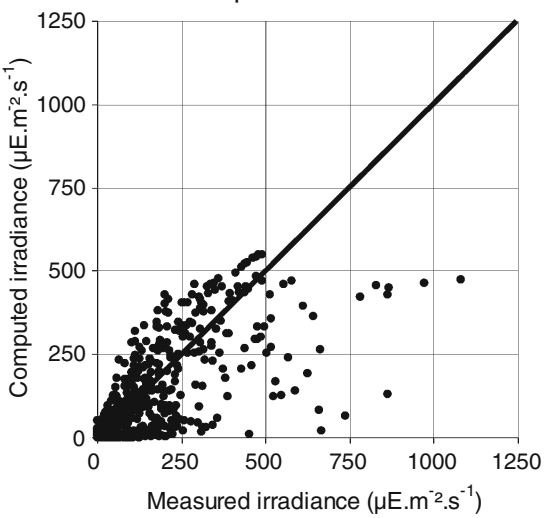

b irradiance - January 1996

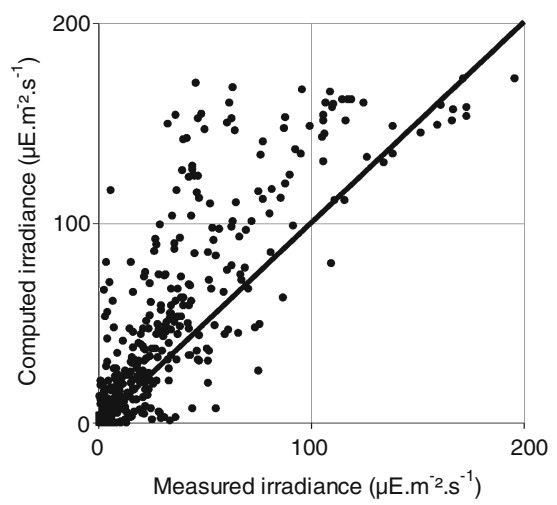

d irradiance - March 1996

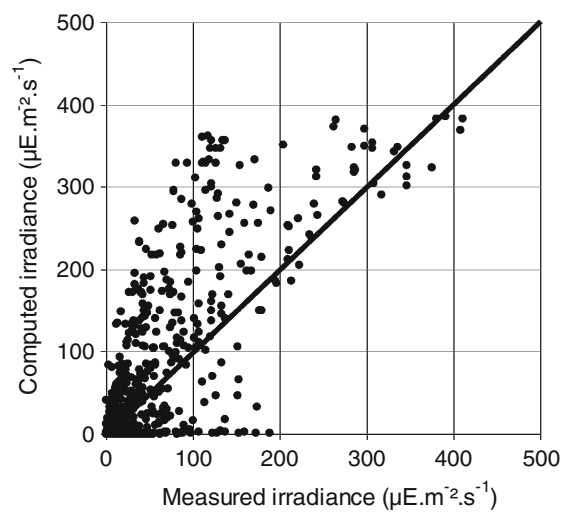

f irradiance - May 1996

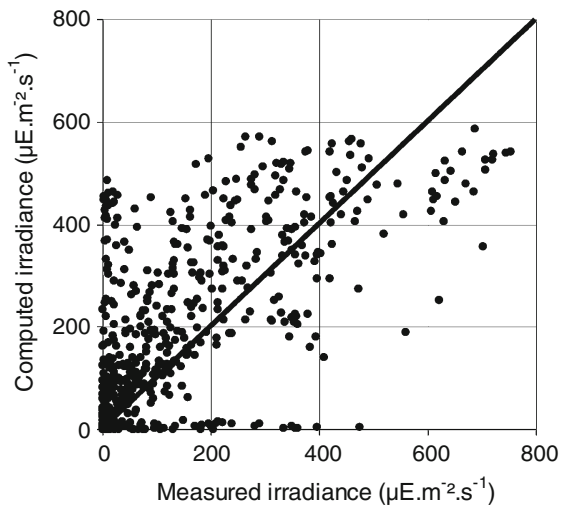

\section{Discussion}

Grain-size analyses clearly showed a similar distribution of surface sediment fractions in most of the Vaccarès lagoon, with the exception of southernmost areas of the Mornès Beach Ridge. In addition, modelling results confirmed the significant control of bottom stress on SS resuspension at the study station. It had a major impact on the resuspension of the clay fraction with frequencies of occurrence reaching $25 \%$ of the time, and a less important impact on the resuspension of the silt fraction, which had a maximum frequency of occurrence of $16 \%$ under strong wind forcing in February. This suggested that the relationships between hydrodynamics and vertical SS dynamics as established at the study station might apply to most of the lagoon. 
Table 1 Root mean squared error (RMSE) and percentage of variance explained $\left(r^{2}\right)$ in bottom irradiance time series, computed at the same study station through (i) a stochastic wind/solids regression (Banas et al., 2005), and (ii) our determinist algorithm for wind-induced diffusion-settling suspended solid concentrations

\begin{tabular}{|c|c|c|c|c|}
\hline \multirow[t]{2}{*}{ Period } & \multicolumn{2}{|c|}{ (i) Stochastic model (Banas et al., 2005) } & \multicolumn{2}{|c|}{ (ii) Determinist diffusion-settling model } \\
\hline & $r^{2}(\%)$ & RMSE & $r^{2}(\%)$ & RMSE \\
\hline December 1995 & 62 & 21.91 & 65 & 21.90 \\
\hline January 1996 & 76 & 15.58 & 78 & 17.01 \\
\hline February 1996 & 42 & 33.57 & 45 & 36.76 \\
\hline March 1996 & 68 & 49.86 & 69 & 46.32 \\
\hline April 1996 & 70 & 70.62 & 64 & 78.08 \\
\hline May 1996 & 63 & 91.64 & 58 & 109.38 \\
\hline Total 6 months & 66 & 76.23 & 61 & 84.81 \\
\hline
\end{tabular}

Table 2 Results of the 1D vertical SS modelling

\begin{tabular}{|c|c|c|c|c|c|c|}
\hline & December & January & February & March & April & May \\
\hline Criterium value & 1.9 & 3.1 & 16.9 & 4.4 & 3.2 & 16.5 \\
\hline$\tau_{\mathrm{R}}$ Maximum $\left(10^{-2} \mathrm{Nm}^{-2}\right)$ & 7.1 & 8.0 & 13.5 & 17.4 & 10.1 & 11.7 \\
\hline$\tau_{\mathrm{R}}$ Time averaged $\left(10^{-2} \mathrm{Nm}^{-2}\right)$ & 0.5 & 0.7 & 1.7 & 1.2 & 1.1 & 1.1 \\
\hline$\%$ Of time with no resuspension & $83 \%$ & $79.7 \%$ & $58.5 \%$ & $66.8 \%$ & $71.8 \%$ & $71 \%$ \\
\hline$\%$ Of time with clay resuspension & $15.1 \%$ & $17 \%$ & $25.5 \%$ & $25.2 \%$ & $21.5 \%$ & $22.2 \%$ \\
\hline$\%$ Of time with clay + silt resuspension & $1.9 \%$ & $3.3 \%$ & $16 \%$ & $8 \%$ & $6.7 \%$ & $6.8 \%$ \\
\hline$\%$ Of time with bottom irradiance I: $0<\mathrm{I}<1 \% I_{0}$ & $10.2 \%$ & $21.5 \%$ & $52.5 \%$ & $32.3 \%$ & $26.3 \%$ & $28.5 \%$ \\
\hline$\%$ Of time with bottom irradiance I: $1 \% I_{0}<\mathrm{I}<10 \% I_{0}$ & $24.3 \%$ & $15 \%$ & $15 \%$ & $14.5 \%$ & $19.7 \%$ & $11.3 \%$ \\
\hline$\%$ Of time with bottom irradiance I: $10 \% I_{0}<\mathrm{I}<50 \% I_{0}$ & $65.5 \%$ & $63.5 \%$ & $32.5 \%$ & $53.2 \%$ & $54 \%$ & $60.2 \%$ \\
\hline
\end{tabular}

Maximum and time averaged values of bottom stress; \% of time with re-suspension of respective SS fractions; \% of time with varying bottom irradiance

Sediment particles largely consisted of calcite grains, quartz and clay minerals, which principally comprised chlorite and illite. Sediment particles were very similar in nature to those found in the modern terrigenous load of the Rhône River (Chamley, 1971). This similarity in composition, together with the absence of authigenesis and the scarcity of microfossil remains, suggested that surface sediments of the Vaccarès lagoon were derived from the suspended load of the Rhône. Sediment particles were probably brought to the lagoon via four canals that drain the delta plain, and are especially active during and after flood events. Laboratory experiments have shown that the terrigenous load of the Rhône River is poorly reactive to salt-induced flocculation and that the behaviour of sand and silt-sized particles is principally controlled by settling and dilution processes (Thill et al., 2001). These processes probably dominated in the Vaccarès lagoon where salinity drastically decreased below $10 \mathrm{~g}^{-1}$ after the severe floods of 1993. In contrast, the behaviour of the smaller clay and colloid fractions looked more complex and it was probable that aggregation, break-up mechanisms and/or primary production might interfere with settling processes.

Mineralogical investigations conducted on the terrigenous load of the Rhône River have shown that illite predominates over chlorite in the finest sediment sizes, whereas chlorite prevails in coarser sediment sizes (Chamley, 1971). It is remarkable that chlorite predominated over illite in the finest clay fraction of the Vaccarès lagoon, illustrating the probable importance of particle break-up in this dynamic environment. Therefore, it is likely that flocculation and related consequences on the cohesion of sediment particles only played a minor role in the accumulation and reworking of surface sediments in the Vaccarès lagoon. It was likely that sand and silt particles 
settled as current velocities decreased following strong wind events. However, the behaviour of the smallest sediment particles progressively deviated from settling principles as they decreased in size. As a consequence, the fine clay and colloid fractions might remain in suspension until flocculation occurred. The fine clay and colloid fractions, which occurred as minor amounts only in the Vaccarès lagoon, might account for part of the turbidity recorded under calm conditions that followed strong wind events, and therefore might affect bottom irradiance.

The computed time series of SS concentration featured some major peaks higher than $1,200 \mathrm{mg}^{-1}$ (winds $>15 \mathrm{~ms}^{-1}$ ) and even reaching 2,000 $\mathrm{mg} \mathrm{l}^{-1}$ in March 1996 (maximum wind $18 \mathrm{~ms}^{-1}$ ). Unfortunately, we were only able to collect a few values of SS at high wind speed: SS values above $0.7-0.8 \mathrm{~g}^{-1}$ were measured in February and May 1996 with winds ranging between 14 and $16 \mathrm{~ms}^{-1}$. Although we did not have additional field measurements during very strong wind events, model results suggested that the maximum value of $2,000 \mathrm{mg} \mathrm{l}^{-1}$ could potentially be considered as the theoretical limit for wind induced SS concentrations at our study station in the eastern Vaccarès lagoon.

Modelling results confirmed that high levels of bottom irradiance (between 10 and $50 \%$ of surface irradiance) remained available more than half of the time, even reaching $65 \%$ of the time in winter, except in February. Although light availability fluctuated widely during the study period, high attenuation of light occurred too infrequently to prevent the establishment or maintenance of seagrass beds. Moreover, lower levels of bottom irradiance (between 0 and $1 \%$ of surface irradiance) only occurred 30 and $10 \%$ of the time in spring and winter, respectively, with the exception of February (53\%). Indeed, the computed time-series of irradiance for February 1996 presented a very particular pattern compared with the other monthly periods of our study, showing a drastic difference in the range of values before and after the wind storm that occurred in the middle of the month. Computed irradiances matched measurements during the first half of the month when wind forcing was moderate, but they were several times larger than measurements at the end of the month, after the wind storm. This discrepancy in the model performance in February 1996, a period of highly contrasting wind forcing, might explain the relatively low level of global correlation between computed and measured irradiance values $\left(r^{2}=0.45, P<0.001, n=1,344\right)$. The over-estimation of computed irradiances following strong wind events was interpreted as the impact on measurements of an additional turbidity transported from other parts of the lagoon by windinduced horizontal advection, still operating after the storm and not taken into account in our $1 \mathrm{D}$ vertical model.

In winter (December 1995, January, February and March 1996), regressions between computed and observed irradiances were in relatively good agreement with measurements at higher values, but irradiances were over-estimated at lower values $\left(<100,100,150\right.$ and $200 \mu \mathrm{E} \mathrm{m}^{-2} \mathrm{~s}^{-1}$, respectively). In addition, time series in winter confirmed computed irradiances were in relatively good agreement with measurements for intervals characterized by moderate SS concentrations related to weak wind forcing. Conversely, irradiances were over estimated for periods of higher SS concentrations that follow strong wind events, as in December 1995 and January 1996 with SS peaks of up to 400 and $500 \mathrm{mg} \mathrm{l}^{-1}$, respectively. Moreover, a storm-induced peak of computed SS concentration, reaching 2,000 $\mathrm{mg}^{-1}$ early in March 1996 was followed by a 5 day interval of over-estimated computed irradiances. This overestimation of computed irradiances was related to an under-estimation of SS concentrations by the model in winter following strong wind events. This result emphasized the significant contribution of turbid water masses transported by the wind-induced horizontal circulation throughout the lagoon. This first hypothesis was supported by the results of our $2 \mathrm{D}$ horizontal hydrodynamic model. Indeed, model results confirmed that high current velocities with a mean vertical averaged value of $8 \mathrm{~cm}^{-1}$ allowed water masses to cross the entire lagoon (maximum length of $12 \mathrm{~km}$ ) within a time-span of 2 days, or even in half a day if we considered the maximum velocity of $26 \mathrm{~cm}^{-1}$. Moreover, model results showed that the study station was directly under the influence of NW wind-induced currents flowing from the southern shore, the most turbid zone of the lagoon due to the local maximum currents and waves. In addition, NW wind-induced eddy structures increased the residence time of turbid waters in the lagoon over time intervals of several days after the wind ceased. 
In this hydrodynamic context, it was possible to consider that an enhanced load of the finest sediment fractions in the water masses, still circulating throughout the lagoon after a storm event, resulted in an increased SS concentration at the study station.

In spring (April and May 1996), regressions between computed and observed irradiances showed computed irradiances in relatively good agreement with measurements in April, or slightly overestimated in May, for lower values. Conversely, regressions showed under-estimated irradiances for higher values $>300$ and $400 \mu \mathrm{E} \mathrm{m}^{-2} \mathrm{~s}^{-1}$, respectively. In addition, time series in spring confirmed computed irradiances were under-estimated when compared with measurements for intervals characterized by over-estimated SS concentrations by the $1 \mathrm{D}$ vertical SS model. In April 1996 for example, a period of low computed and measured SS concentrations (below $200 \mathrm{mg}^{-1}$ ) between 600 and 1,100 time steps of computation, corresponded to a period of weak wind forcing but under-estimated computed irradiances. Moreover in May 1996, computed irradiances were under-estimated at about 600 time steps of computation, when a storm-induced peak of computed SS concentrations (reaching 1,200 $\mathrm{mg}^{-1}$ ) occurred without a total extinction of measured bottom irradiance. These under-estimations of computed irradiances could be related to the growth of submerged vegetation, particularly development of the canopy, which decreased the velocity of currents, thereby enhancing the settlement of particles and preventing their resuspension. This second hypothesis is supported by recent field observations, laboratory experiments and computations, which confirm the reduction in current and bed shear stress, and associated sediment trapping, within seagrass beds during the growth season (Gacia et al., 1999; Heiss et al., 2000; Banas et al., 2002; James et al., 2004; Bos et al., 2007).

In addition, it was noteworthy that the root mean squared errors of bottom irradiance time series computed by our determinist $1 \mathrm{D}$ vertical diffusionsettling model, were quite similar to those obtained by Banas et al. (2005) through a stochastic regression of SS measurements and wind velocities. Banas et al. (2005) showed that a stochastic model, based on simple relationships between weather data and SS, could be an effective tool for managing aquatic systems and macrophyte growth. Nevertheless, it was difficult to improve this stochastic approach as processes implicated in irradiance attenuation were not described. The similarity in PAR prediction obtained with stochastic and determinist models indicated that the dominant processes involved in re-suspension (e.g. vertical eddy diffusion and settling of sediment particles) were efficiently taken into account in the determinist formulation and allowed better understanding of processes governing irradiance attenuation in this shallow aquatic system.

\section{Conclusion}

Depending on season, a discrepancy existed between the stochastic and deterministic models was observed. In winter (December to March), the determinist model explained slightly more variance than the stochastic model. Conversely, the deterministic model is slightly less efficient in spring. This result reinforced our hypothesis concerning the impact on sediment mobility of the increasing activity of the submerged vegetation $Z$. noltii in spring.

This study demonstrated that in a wind-forced shallow system, a basic determinist 1D vertical formulation of re-suspension, turbulent diffusion and settling of SS, even when limited to the two dominant sediment fractions (silt/clay) of the local sediment and the water column of one single study station, sufficiently explained up to $61 \%$ of the total variance of the bottom irradiance time series measured at this station. Moreover, the results obtained by our determinist model of vertical sediment dynamics reached the same level of efficiency, in term of percentage of variance explained in irradiance time series, as those obtained with the same data set by the stochastic model of Banas et al. (2005). This result confirmed that our determinist formulations contained a relevant set of processes controlling the local wind-induced dynamics of SS.

Nevertheless, although our 1D vertical SS model was partly forced by currents computed by a $2 \mathrm{D}$ horizontal model of circulation, our study remained a 1D vertical SS modelling that could not provide any spatial computations of the sediment dynamics throughout the lagoon. Therefore, percentages of variance in irradiance time series which were not explained by the 1D vertical determinist algorithms might be controlled by additional processes not considered in the 1D present model. Such processes 
included the wind-induced horizontal advection and the seasonal development of a submerged canopy. However, these additional processes contributed for less than $40 \%$ of the total variance explained in bottom irradiance time-series. The increased load of the finest SS fractions due to prevailing horizontal transport dominated in winter, whereas the decreased load of coarser solid fractions, related to the expansion of the submerged vegetation, dominated in spring. This suggests new modelling perspectives focused on the development of 3D coupled water and sediment dynamics models and integrated physical biogeochemical models are needed.

\section{References}

Aveytua-Alcazar, L., V. F. Camacho-Ibar, A. J. Souza, J. I. Allen \& R. Torres, 2008. Modelling Zostera marina and Ulva spp. in a coastal lagoon. Ecological Modelling 218: 354-366.

Banas, D., G. Masson, L. Leglize \& J. C. Pihan, 2002. Temporal variations of sedimentation in shallow freshwater systems. Archiv für Hydrobiologie 153: 623-634.

Banas, D., P. Grillas, I. Auby, F. Lescuyer, E. Coulet, J. C. Moreteau \& B. Millet, 2005. Short time scale changes in underwater irradiance in a wind-exposed lagoon (Vaccarès lagoon, France): efficiency of infrequent field measurements of water turbidity or weather data to predict irradiance in the water column. Hydrobiologia 551: 3-16.

Bernard, G., C. F. Boudouresque \& P. Picon, 2007. Long term changes in Zostera meadows in the Berre lagoon (Provence, Mediterranean Sea). Estuarine Coastal and Shelf Sciences 73: 617-629.

Best, E. P. H., C. P. Buzzelli, S. M. Bartell, R. L. Wetzel, W. A. Boyd, R. D. Doyle \& K. R. Campbell, 2001. Modeling submersed macrophyte growth in relation to underwater light climate: modeling approaches and application potential. Hydrobiologia 444: 43-70.

Blindow, I., 1992. Long- and short-term dynamics of submerged macrophytes in two shallow eutrophic lakes. Freshwater Biology 28: 15-27.

Bos, A. R., T. J. Bouma, G. L. J. de Kort \& M. M. van Katwijk, 2007. Ecosystem engineering by annual intertidal seagrass beds: sediment accretion and modification. Estuarine, Coastal and Shelf Science 74: 344-348.

Byun, D. S., X. H. Wang, M. Zavatarelli \& Y. K. Cho, 2007. Effects of resuspended sediments and vertical mixing on phytoplankton spring bloom dynamics in a tidal estuarine embayment. Journal of Marine Systems 67: 102-118.

CERC, 1975. Shore Protection Manual, Vol. I. US Army Corps of Engineers, Washington.

Chamley, H., 1971. Recherches sur la sédimentation argileuse en Méditerranée. Sciences Géologiques 35, Strasbourg.

Charpentier, A., P. Grillas, F. Lescuyer, E. Coulet \& I. Auby, 2005. Spatio-temporal dynamics of a Zostera noltii community over a period a fluctuating salinity in a shallow coastal lagoon, southern France. Estuarine, Coastal and Shelf Science 64: 307-315.

Chauvelon, P., 1996. Hydrologie quantitative d'une zone humide méditerranéenne aménagée: Le bassin de Fumemorte en Grande Camargue, delta du Rhône. PhD Thesis, University of Montpellier.

Christofor, S., A. Vadineanu, G. Ignat \& C. Ciubuc, 1994. Factors affecting light penetration in shallow lakes. Hydrobiologia 275(276): 493-498.

Deer, W. A., R. A. Howie \& J. Zussman, 1992. An Introduction to the Rock-Forming Minerals. Longman Scientific and Technical, Harlow.

Duarte, C. M., 1991. Seagrass depth limits. Aquatic Botany 40: 363-377.

Dunton, K. H., 1994. Seasonal growth and biomass of the subtropical seagrass Halodule wrightii in relation to continuous measurements of underwater irradiance. Marine Biology 120: 479-489.

Edgard, L., 1999a. Experimental analysis of structural versus trophic importance of seagrass beds. I. Effects on macrofaunal and meiofaunal invertebrates. Vie et milieu 49: 239-248.

Edgard, L., 1999b. Experimental analysis of structural versus trophic importance of seagrass beds. II. Effects on fishes, decapods and cephalopods. Vie et milieu 49: 249-260.

Gacia, E., T. C. Granata \& C. M. Duarte, 1999. An approach to measurements of particle flux and sediment retention within seagrass Posidonia oceanica meadows. Aquatic Botany 65: 255-268.

Heiss, W. M., A. M. Smith \& P. K. Probert, 2000. Influence of the small intertidal seagrass Zostera novazelandica on linear water flow and sediment texture. New Zealand Journal of Marine and Freshwater Research 34: 689-694.

Hilton, J. A., 1985. A conceptual framework for predicting the occurrence of sediment focusing and sediment redistribution in small lakes. Limnology and Oceanography 30: $1131-1143$

Holtzapffel, T., 1985. Les minéraux argileux. Préparation, analyse diffractométrique et détermination. Société Géologique du Nord 12.

James, W. F., J. W. Barko \& M. G. Butler, 2004. Shear stress and sediment resuspension in relation to submersed macrophyte biomass. Hydrobiologia 515: 181-191.

Kouchi, N., M. Nakaoka \& H. Mukai, 2006. Effects of temporal dynamics and vertical structure of the seagrass Zostera caulescens on distribution and recruitment of the epifaunal encrusting bryozoa Microporella trigonellata. Marine Ecology 27: 145-153.

Kristensen, P., M. Søndergaard \& E. Jeppesen, 1992. Resuspension in a shallow eutrophic lake. Hydrobiologia 228: 101-109.

Longstaff, B. J. \& W. C. Dennison, 1999. Seagrass survival during pulsed turbidity events: the effects of light deprivation on the seagrasses Halodule pinifolia and Halophila ovalis. Aquatic Botany 65: 105-121.

Madsen, J. D., P. A. Chambers, W. F. James, E. W. Koch \& D. F. Westlake, 2001. The interaction between water movement, sediment dynamics and submersed macrophytes. Hydrobiologia 444: 71-84. 
Miller, M. C., I. N. McCave \& P. D. Komar, 1977. Threshold of sediment motion under unidirectional currents. Sedimentology 24: 507-527.

Millet, B., 1989. Modélisation hydrodynamique du bassin de Thau. Validation écologique d'un modèle numérique de circulation. Oceanologica Acta 12: 37-46.

Millet, B. \& O. Guelorget, 1994. Spatial and seasonal variability in the relationships between benthic communities and physical environment in a lagoon ecosystem. Marine Ecology-Progress Series 108: 161-174.

Moore, K. A., R. L. Wetzel \& R. J. Orth, 1997. Seasonal pulses of turbidity and their relations to eelgrass Zostera marina L. survival in an estuary. Journal of Experimental Marine Biology and Ecology 215: 115-134.

Penhale, P. A., 1977. Macrophyte-epiphyte biomass and productivity in eelgrass Zostera marina L. and its epiphytes. Journal of Experimental Marine Biology and Ecology 42: 113-123.

Peterson, E. L., 1999. Benthic shear stress and sediment condition. Aquacultural Engineering 21: 85-111.

Pihl, L., S. Baden, L. Kautsky, P. Ronnback, T. Soderqvist, M. Troell \& H. Wennhage, 2006. Shift in assemblage structure due to the loss of seagrass Zostera marina habitats in Sweden. Estuarine, Coastal and Shelf Sciences 67: 123-132.

Plus, M., A. Chapelle, P. Lazure, I. Auby, G. Levavasseur, M. Verlaque, T. Belsher, J. M. Deslou-Paoli, J. M. Zaldivar \& C. N. Murray, 2003. Modelling of oxygen and nitrogen cycling as a function of macrophyte community in the Thau lagoon. Continental Shelf Research 23: 1877-1898.

Preen, A. R., W. J. Lee Wong \& R. G. Coles, 1995. Flood and cyclone related loss, and partial recovery, of more than $1000 \mathrm{~km}^{2}$ of seagrass in Hervey Bay, Queensland, Australia. Aquatic Botany 52: 3-17.
Sheng, Y. P. \& T. Kim, 2008. Skill assessment of an integrated modelling system for shallow coastal and estuarine ecosystems. Journal of Marine Systems 76: 212-243.

Soulsby, R., 1997. Dynamics of Marine Sands. Thomas Telford Publisher, London.

Stefan, H., J. Cardoni, F. Schiebe \& C. Cooper, 1983. Model of light penetration in a turbid lake. Water Resources Research 19: 109-120.

Thill, A., S. Moustier, J. M. Garnier, C. Estournel, J. J. Naudin \& J. Y. Bottero, 2001. Evolution of particle size and concentration in the Rhône river mixing zone: influence of salt flocculation. Continental Shelf Research 21: 21272140.

Vella, C., T. J. Fleury, G. Raccasi, M. Provansal, F. Sabatier \& M. Bourcier, 2005. Evolution of the Rhône delta plain in the Holocene. Marine Geology 222-223: 235-265.

Vermaat, J. E., F. C. A. Verhagen \& D. Lindenburg, 2000. Contrasting responses in two populations of Zostera noltii Hornem. to experimental photoperiod manipulation at two salinities. Aquatic Botany 67: 179-189.

Vlag, D., 1992. A model for predicting waves and suspended silt concentration in a shallow lake. Hydrobiologia 235/ 236: 119-131.

Winterwerp, J. C., 1989. Cohesive sediments. In flow induced erosion of cohesive beds. A literature survey. Rijkswaterstaat-Delft Hydraulics, Delft. Report 25.

Zieman, J. C. \& R. G. Wetzel, 1980. Productivity in seagrasses: methods and rates. In Philips, R. C. \& C. P. McCoy (eds), Handbook of Seagrass Biology. Garland STPM Press, New York: 87-116.

Zimmerman, R. C., A. Cabello-Pasini \& R. S. Alberte, 1994. Modeling daily production of aquatic macrophytes from irradiance measurements: a comparative analysis. Marine Ecology-Progress Series 114: 185-196. 